\title{
Influence of Waste Glass Powder on Compressive Strength of Sulfate Resistance Portland Cement
}

Elham Abd Al Majeed*

College of Materials Engineering, University of Babylon, Iraq

\begin{abstract}
Today glass is used in many forms and it has a short life due to brittleness and ease of breakage. After breakage it either store until re-use or send to landfills, since the glass material is un-degradable so its stockpiling in landfills considered an unfriendly solution for the environments, thus there is great need to take advantage of glass waste such as using in mortar and concrete as additive.

This research deals with studying the effect of adding (incandescent lamps) as a glass powder waste to cement mortar on mechanical properties, where the glass waste is used as additive after converting it into micro powder, and mixed with cement in the proportions $(0 \%, 5 \%, 10 \%, 15 \%)$ and then mixed with sand in $3: 1$ ratio to create cement mortar and then poured into molds.

And then put in humidity basin and after 24 hours the cubes removed from molds and treated in clean fresh water saline solution where the salt is $3 \% \mathrm{NaCl}$ - and finally in basal solution where the base is $3 \% \mathrm{NaOH}-$ for 7,28 days, and then mechanical tests is made where the test used in this research is the compressive strength.

It has been noted that there are differences in the compressive strength when immersed in various solvents. The samples submerged with water only have higher strength than that submerged in $\mathrm{NaCl}$ solution which in turns have higher strength than that immersed in $\mathrm{NaOH}$, also strength increases with immersion time (i.e. Compressive strength of samples submerged at 28 days better than that submerged at 7 days).
\end{abstract}

Keywords: Portland cement; Glass; Composite materials; Compressive strength

\section{Introduction}

Concrete is one of the components in a probable building material that may have a desired strength and workability at minimum expense. A proportioned mixer of cement, sand and gravel or other aggregates and water to harden by designing carefully in forms of shape and dimensions of the desired structure with good durability [1].

Cement is a necessary ingredient in concrete and mortar, it consists of materials that contain oxides of calcium, silicon, aluminum and iron. The size that can be used as aggregates depends on factors such as the size and shape of the concrete member to be cast, grading also influences the workability the concrete that achieved by the fine and coarse aggregate. Water is mixed with cement and starts a chemical reaction hydration, the cement content use enough water for good workability to achieve paste [2].

Many researchers have entered the glass waste powder to the mortar or concrete, some of them replaced it with cement, others with the sand and other researchers replaced both of them, so the followings are some studies.

Ahmad Shayan used glass as aggregate of different sizes include coarse glass aggregate $(4.75 \mathrm{~mm}-12 \mathrm{~mm})$, fine glass aggregate $(0.15$ $\mathrm{mm}-4.75 \mathrm{~mm}$ ) and glass powder GLP finer than 10 micro meters and it has been found that the glass is unstable in alkaline environment due to alkali -silica reaction to create silica gel that is capable of swelling causing damages to concrete, and this reaction can be avoided by further grinding for glass were it integrated into the concrete as Pozzolanic material, and he also showed that using glass powder is more economically than using silica foam, fly ash and cement [3].

Researcher Amir Abdul rahman and saadi chertoh found that compressive strength in age of 28 days for standard is $42.3 \mathrm{MPa}$, so for glassy concrete mixes - in the proportion of $15 \%$ glass instead of sand for the first sample, $10 \%$ glass instead of cement for the second sample, and in the third sample each sand and cement is replaced in the same previous proportions by glass - is respectively $(39.2,39.1$, and 40.9) $\mathrm{MPa}$ and noticeable there is no respectable differences in the compressive strength between the four mixes. For the possibility of replacing quantities of cement, sand, or both, by powder glass waste with the absence of significant differences in the resistance, the concrete, glass production is economical compared to normal concrete, which has the same resistance [4].

Parviz Soroushian replaced $20 \%$ of the cement weight by mixedcolor waste glass as a powder, and he found that grinding the glass to very fine powder (micro particles) experiencing useful interaction with cement hydrate to compose calcium silicate hydrate (C-S-H) which is useful for strengthening the structure and properties of concrete. And he also found that replacing part of the cement by ground color glass waste, offers chemical stability, enhance the resistance to absorb moisture, durability, abrasion resistance and improve strength in the long-term [5].

In this research Roz-Ud-Din Nassar and Parviz Soroushian reviewed the possibility of manufacturing of recycled aggregate concrete

${ }^{*}$ Corresponding author: Elham Abs Al-Majeed, College of Materials Engineering University of Babylon, Iraq, Tel: 7801006256; E-mail: drelham_2003@yahoo.com

Received November 23, 2017; Accepted January 04, 2017; Published January 11,2018

Citation: Al Majeed EA (2018) Influence of Waste Glass Powder on Compressive Strength of Sulfate Resistance Portland Cement. Ind Eng Manage S3: 003. doi: 10.4172/2169-0316.S3-003

Copyright: (c) 2018 Khafaji NSL, et al. This is an open-access article distributed under the terms of the Creative Commons Attribution License, which permits unrestricted use, distribution, and reproduction in any medium, provided the original author and source are credited. 
with milled waste glass in particle with size $(13 \mu \mathrm{m})$ that was utilized as a partial replacement for cement, which made to less pozzolanic reactions with cement hydrates, forming secondary calcium silicate hydrate (C-S-H). All these help to improved strength and durability of this mixture.

Positive modifications in the paste structure of the hydrated cement and the interior transmission zones in recycled aggregate concrete happen due to the reactions that occur. Waste glass milling was found to repress alkali-silica reactions. The strength which advancement in 56 days provision an indirect measurement of the pozzolanic action of milled waste glass which have a high surface area that variation the kinetics of chemical reaction to achieve pozzolanic reaction employing an obtainable alkali before fabrication of ASR gel [6].

In this work Ankur Meena shows that fine glass powder was used as substitution cement in concrete to assess the efficiency of pozzolanic and compared it with other pozzolanic materials such as silica fume and fly ash.

It was found out the influence of $15 \%$ and $30 \%$ alteration of cement by silica fume, fly ash and glass powder on compressive strength and durability in the mode of capillary absorption. Using glass powder of size $150 \mu \mathrm{m}-100 \mu \mathrm{m}$ and glass powder of size less than $100 \mu \mathrm{m}$ to estimate the effect of particle size.

So the waste glass finer than $100 \mu \mathrm{m}$ was defined a pozzolanic behavior, at early stage of hydration it reacts with lime to form a denser cement matrix with extra CSH gel and the durability of concrete also increases [7].

Gautam et al. use manufactured products such as sheet glass, bottles, glassware, and vacuum tubing that helps to save a lot of energy with low cost production. By using waste glass as a fine aggregate replacement, the strength increased up to $20 \%$ after $28 \mathrm{~d}$. Also the results showed a decrease in strength at (30-40\%) as a fine aggregate replacement of waste glass. So it was found that $(10 \%)$ is the optimum replacement level of waste glass as fine aggregate [8].

In this work the glass beads have been used in concrete production by Serniabat et al. Crushed glass in a size of $5 \mathrm{~mm}-20 \mathrm{~mm}$, and glass marble of $20 \mathrm{~mm}$ size as coarse aggregate mixing together. By using 9 different concrete, Portland cement, type 1 and finer sand less than 0.5 $\mathrm{mm}$ were used to manufacture standard concrete cylinders. Concrete specimens at various ages the compressive strength were tested. A maximum compressive strength which is 3889 psi, can be gotten by the mixing equiponderant ratio of glass beads and round marbles. So the glass beads behaved as a boater in bonds, but have lower strength, while marbles are no better in bonding but are so strong [9].

Junior et al. used flat glass powder in proportions of 5\%, $10 \%$ and $15 \%$ as a substitute for sand, and $\mathrm{W} / \mathrm{C}$ ratio $0.50,0.55$ and 0.58 for a period of immersion 7, 14 and 28 days. They concluded that concrete containing $20 \%$ of the flat glass powder is proper for structural applications with $\mathrm{W} / \mathrm{C}$ ratio 0.55 and they found that compressive strength is affected by the water proportion more than glass used as a substitute. So the compressive strength of cement concrete was found to be increased as use of flat glass powder [10].

The goal of this study was to replace the Waste Glass Powder (WGP) of cement in saw dust composite brick. WGP was used for replacement cement partially at $0 \%, 5 \%, 10 \%, 15 \%, 20 \%, 25 \%$, and $30 \%$ with binder sand mixing ratio of 1:6. A series of tests were conducted by Omoniyi et al. study the compressive strength, water absorption, capillary water absorption and volume porosity. The researchers showed that WGP can be used as an alternative for cement material up to $30 \%$ in size less than $100 \mu \mathrm{m}$ to stop the reaction of alkali silica and get benefit without any opposite effect. So the results shown increasing durability of composite brick, which is affected on volume porosity, water absorption, capillary absorption and in densities [11].

The waste glass is widely used in different fields so in this research, Shaikh and Bachhav used waste glass powder and crushed glass particles (CGP) as partial replacement of cement [1]. As well as the use of it retained on $1.18 \mathrm{~mm}$ and $2.36 \mathrm{~mm}$ IS sieve as a partial replacement for sand, which gives good value of the strength of concrete. The attempts have been made to alternative the cement as well as sand with equal combination waste glass powder and crushed glass particles by $5 \%, 10 \%, 15 \%$ and $20 \%$ replacement and study its effect on the strength of concrete after 7 days and 28 days of curing. So the compressive strength increases after 28 days by $9.25 \%, 38.50 \%, 70.80 \%$, and $33.09 \%$, respectively. And the flexural strength increases after 28 days by $5.88 \%$, $30 \%, 44.85 \%$, and $13.97 \%$, respectively. Compared with conventional concrete, the glass powder concrete increases the compressive, tensile and flexural strength effectively at $15 \%$ combine replaced.

Sikora et al. studied properties of cement mortars and estimated the possibility of producing it with brown soda-lime waste glass, amorphous nanosilica and nanocrystalline titanium dioxide that were resolved in terms of waste glass content [12]. Brown waste glass at ratios of $25 \%, 50 \%, 75 \%$ and $100 \%$ by weight, can be used as an alternative of quartz sand. This work has shown that waste glass (up to 100\%) can be act as a good replacement to manufacture cement mortars, however nanosilica is combined. Beside this a favorable influence of waste glass aggregate for bactericidal properties of cement mortar was spotted.

So in this study, get good results by mixing (cement, sand and water) with the different ratio of waste glass (incandescent lamps) which shows excellent compressive strength according to ASTM, and study behavior of it in a different environment when the samples were exposed to aggressive environments, in concentrations of chloride ions and hydroxide ions. At the same time reduce the waste (incandescent lamps) by diversion large quantities of it in landfills.

\section{Materials}

1. Glass waste: incandescent lamps were used as glass waste powder.

2. Sulfate resistance Portland cement.

3. Standard sand that has been treated with hot HCL and deal with the following conditions:

- No more than $0.25 \%$ should be lost by washing with HCL.

- The entire amount should pass sieve 85 micron, and not more than $10 \%$ should pass sieve 600 micron.

4. Oil to lubricate the molds.

5. Salt solution where the user salt is $3 \% \mathrm{NaCl}$ of the weight of water. 6. Basic solution where the user base is $3 \% \mathrm{NaOH}$ of the weight of water.

7. Distilled water must be used to clean the samples and to free of dirt.

After preparing the standard (cement, sand and water) with different amount of waste glass in order to make samples ready to test, as shown in Table 1.

\section{Preparing Samples for Test}

The experimental work related to this project done in cement and 


\begin{tabular}{|c|c|c|c|c|c|}
\hline Samples & $\begin{array}{c}\text { Samples } \\
\text { No }\end{array}$ & $\begin{array}{c}\text { Glass } \\
\text { Proportion } \\
\text { \% }\end{array}$ & $\begin{array}{c}\text { Cement } \\
\text { Amount (g) }\end{array}$ & $\begin{array}{c}\text { Sand } \\
\text { Amount (g) }\end{array}$ & $\begin{array}{c}\text { Water } \\
\text { Amount } \\
\text { (ml) }\end{array}$ \\
\hline A & 6 & 0 & 200 & 600 & 80 \\
\hline B & 6 & 5 & 190 & 600 & 79 \\
\hline C & 6 & 10 & 180 & 600 & 78 \\
\hline D & 6 & 15 & 170 & 600 & 77 \\
\hline
\end{tabular}

Table 1: Materials mix proportions (cement, sand and water) with different amount of glass.
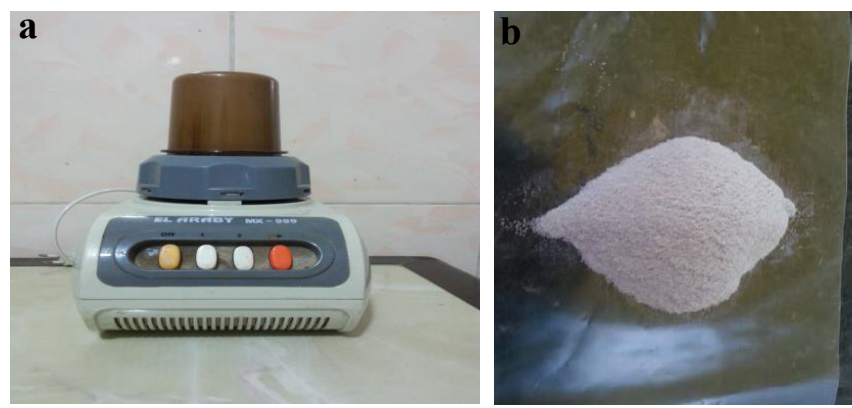

Figure 1: (a) Electric mill, (b) Powder glass.

concrete laboratory that belongs to the building and a ceramic material department as follows:

\section{Grinding mill}

At the beginning a set of incandescent lamps was collected and crushed with a pestle, and then an electric grinding mill was used to get finer size as micro powder as shown in Figure 1.

\section{Grain size of glass}

Grain size of glass powder was detected by the device (Better size 2000 particle size analyzer), where the less particle size is 0.08 microns and larger one is 100 microns.

\section{Rotary mixer and sensitive balance}

The dry bowl and feathers were fixated in the mixer, so the materials put in the bowl and adding the appropriate amount of water in order to mixed them at low speed about (140 \pm 15$)$ revolution per minute, then stop the mixer to scrape the mortar from the bowl walls with 15 seconds and then re-mix using high speed for $4 \mathrm{sec}$, to get the homogeneous mix. The sensitive balance used to measure the weight of materials which give the results directly on the screen with high accuracy.

\section{Molding}

The mixture was transferred to the mold that must be lubricated to prevent sticking the mortar with the internal surfaces and prevent water leakage from the mold to the outside during compaction. A metal molds from cast iron are usually used that has polished and free off deteriorates inner surface. Then fixated on a metal base with screws, these molds must be operable in order to take off the model without any defect or crack. The mold is cubic with dimensions $\left(70^{\star} 70^{\star} 70\right) \mathrm{mm}$ and the area of each face must be $50 \mathrm{~cm}^{2}$ as shown in Figure 2 .

\section{Mechanical vibrator}

This machine is used to compact the mortar automatically, the mold puts on the vibrating machine Figure 3 and keeps working for 2 minutes to compact the mortar carefully. The weight of machine part that base of vibration axis, including the weight of the mold, molded handles, and other devices is approximately $300 \mathrm{~kg}$ with the rotation speed of vibrator axis is $(12000 \pm 400)$ revolution per minute.

After completing the compaction process, take the molds to the humidity basins and stay there for 24 hours and the moisture is not less than $90 \%$. Then take out the models from the molds carefully. Place 6 samples in the basin contain only water, 6 samples in the basin contain $97 \%$ water with $3 \% \mathrm{NaCl}$, and the last 6 samples in the basin contain $97 \%$ water with $3 \% \mathrm{NaOH}$, where each sample stay there for 7 days. The same procedure was repeated for the same number of samples, but immersed in these environments for 28 days. First the samples in age 7 days were extracted from the different environments, and also the samples in age of 28 days were extracted, after this the samples leading to the compressive strength test.

\section{Compressive Strength Testing}

The compression strength test machine Figure 4 is used to know

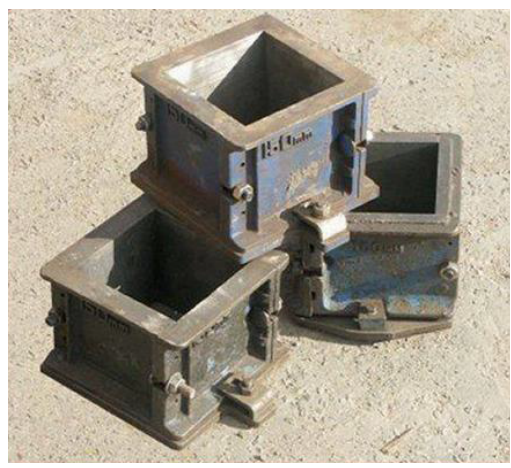

Figure 2: Metal molds.

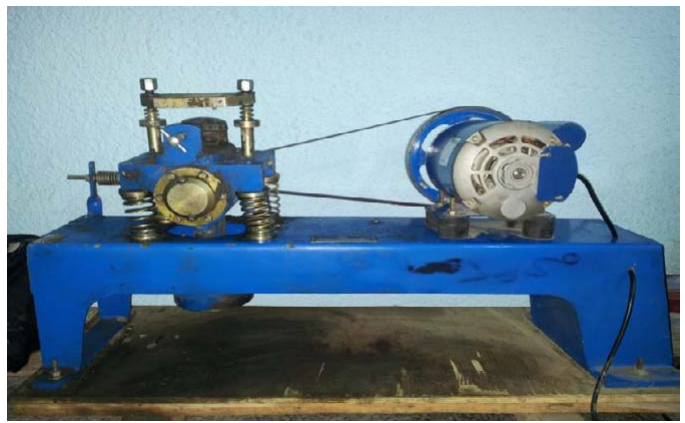

Figure 3: Mechanical vibrator.

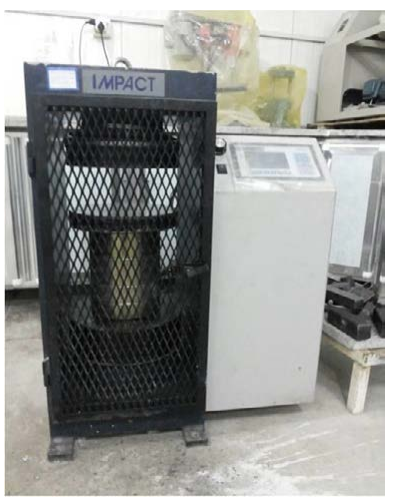

Figure 4: Compressive strength testing machine. 
Citation: Al Majeed EA (2018) Influence of Waste Glass Powder on Compressive Strength of Sulfate Resistance Portland Cement. Ind Eng Manage S3: 003. doi: 10.4172/2169-0316.S3-003

Page 4 of 6

the compressive strength for the samples that have been molded. Set the required load where it ranges between $(0-2000) \mathrm{KN}$, and a graph immediately drawn in the device screen.

\section{Result and Discussion}

\section{Particle size of glass}

Grain size is the most fundamental physical properties. The distribution of different grain sizes affects the engineering properties of the powder. Grain size analysis provides the grain size distribution.

The better size 2000 LD particle size analyzer using for high resolution measurement of particle size distributions which is the most one successful systems for digital image processing. The dry dispersing system adopts Venturi dispersing effect to ensure that powders are in a complete dispersing state when pass test window by the way of shear, inertia, collision, etc. The instrument has outstanding characteristics of high accuracy and reliability, good repeatability, easy operation, fast test speed, and wide test range, etc. Figure 5 shows an average diameter $(\mu \mathrm{m})$ and surface area $\left(\mathrm{SSA}=0.069 \mathrm{~m}^{2} / \mathrm{kg}\right)$. Table 2 shows the measurement of particle size of glass.

\section{Compressive strength test}

24 samples were tested by the compressive strength testing machine as samples in the Table 2 .

Figure 6 shows the effect of adding glass powder waste with different proportions as $(0,5,10,15) \%$ on the mortar compressive strength, whereas increasing the glass proportion, the compressive strength increases because the powder glass reduces the pores since it permeates between larger particles and that increases the density which in return affects. The strength until using $15 \%$ of glass the compressive strength begins to decline due to segregation which reduces the strength. It is also noted that compressive strength increases with immersion time.

Bettersize2000 laser particle size analyzer
Particle size analysis report

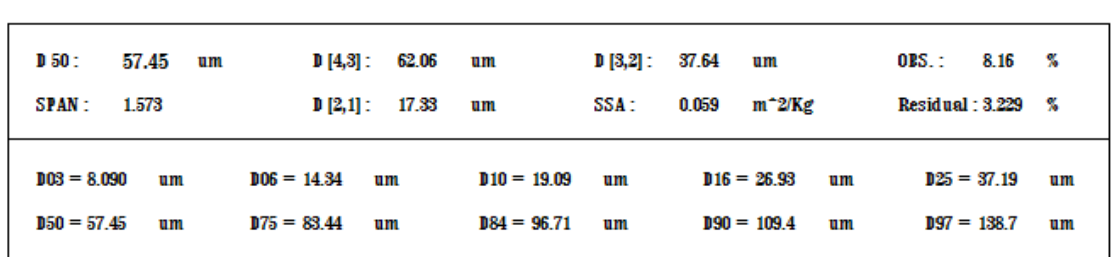

\begin{tabular}{|c|c|c|c|c|c|c|c|c|}
\hline Diam um & Diff\% & Cumu\% & Diam um & Diff\% & Cumu\% & Diam um & Diff\% & Cumus \\
\hline $0.020-0.024$ & 0.00 & 0.00 & $0.911^{-1.161}$ & 0.00 & 0.00 & 44.0456 .13 & 15.42 & 4846 \\
\hline 0.024 .0 .030 & 0.00 & 0.00 & $1.161-1.479$ & 0.00 & 0.00 & 56.1371 .52 & 16.27 & 6473 \\
\hline $0.030-0.039$ & 0.00 & 0.00 & $1.479-1.865$ & 0.00 & 0.00 & 71.52 .91 .14 & 15.86 & 80.59 \\
\hline $0.039-0.049$ & 0.00 & 0.00 & $1.885-2.403$ & 0.00 & 0.00 & $91.14-116.1$ & 1165 & 9224 \\
\hline $0.049-0.063$ & 0.00 & 0.00 & $2.403-8.062$ & 0.00 & 0.00 & $116.1-147.9$ & 5.86 & 9810 \\
\hline $0.063-0.080$ & 0.00 & 0.00 & $3.062-3.902$ & 0.00 & 0.00 & $147.9-188.5$ & 1.80 & 99.90 \\
\hline $0.080-0.102$ & 0.00 & 0.00 & $3.902-4.972$ & 0.08 & 0.08 & $188.5-240.3$ & 0.10 & 100.00 \\
\hline $0.102-0.131$ & 0.00 & 0.00 & $4.972-6.336$ & 1.12 & 1.20 & $240.3-806.2$ & 0.00 & 100.00 \\
\hline $0.131-0.167$ & 0.00 & 0.00 & $6.336-8.074$ & 1.79 & 2.99 & 306.2 .390 .2 & 0.00 & 100.00 \\
\hline $0.167-0.212$ & 0.00 & 0.00 & $8.074-10.28$ & 0.96 & 3.95 & $390.2-497.2$ & 0.00 & 100.00 \\
\hline $0.212-0.271$ & 0.00 & 0.00 & $10.28-1811$ & 1.18 & 5.18 & 497.2 .633 .6 & 0.00 & 100.00 \\
\hline $0.271-0.345$ & 0.00 & 0.00 & $18.11-16.70$ & 2.82 & 7.95 & $633.6-807.4$ & 0.00 & 100.00 \\
\hline $0.345 \cdot 0.440$ & 0.00 & 0.00 & $16.70-21.28$ & 3.84 & 11.79 & $807.4 \cdot 1028$ & 0.00 & 100.00 \\
\hline $0.440-0.561$ & 0.00 & 0.00 & 21.28 .27 .12 & 4.35 & 16.14 & $1028-1311$ & 0.00 & 100.00 \\
\hline $0.561-0.715$ & 0.00 & 0.00 & $27.12-3456$ & 6.20 & 22.34 & $1811-1670$ & 0.00 & 100.00 \\
\hline $\begin{array}{l}0.715-0.911 \\
\end{array}$ & 0.00 & 0.00 & $34.56-44.04$ & 10.70 & 33.04 & $1670-2000$ & 0.00 & 100.00 \\
\hline
\end{tabular}

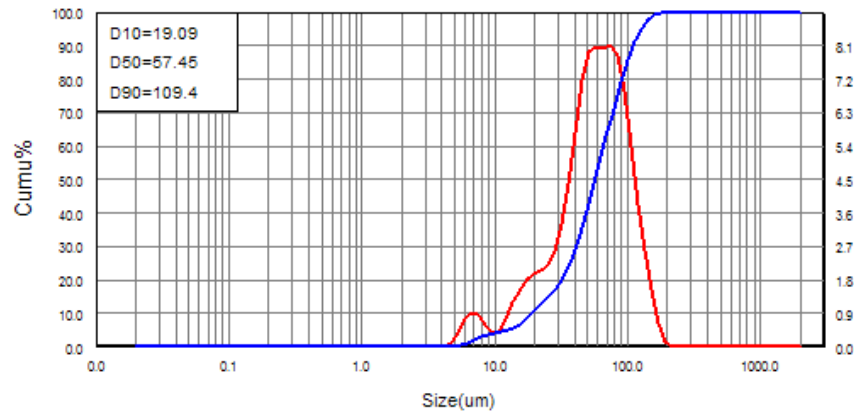

\begin{tabular}{|c|c|}
\hline Diam um & Pereent \\
\hline 1.000 & 0.00 \\
\hline 2.000 & 0.00 \\
\hline 5.000 & 0.10 \\
\hline 10.000 & 3.86 \\
\hline 20.000 & 10.74 \\
\hline 45.000 & 34.28 \\
\hline 75.000 & 67.91 \\
\hline 100.000 & 85.96 \\
\hline 200.000 & 99.97 \\
\hline 300.000 & 100.00 \\
\hline
\end{tabular}

Figure 5: Particle size analysis report of glass. 
Citation: Al Majeed EA (2018) Influence of Waste Glass Powder on Compressive Strength of Sulfate Resistance Portland Cement. Ind Eng Manage S3: 003. doi: 10.4172/2169-0316.S3-003

Page 5 of 6

\begin{tabular}{|c|c|c|c|c|c|}
\hline \multirow[b]{2}{*}{ Glass proportion (\%) } & \multirow[b]{2}{*}{ Immersion type } & \multicolumn{2}{|c|}{ Immersed for 7 days } & \multicolumn{2}{|c|}{ Immersed for 28 days } \\
\hline & & Compressive strength(MPA) & $\begin{array}{l}\text { Load } \\
\text { (KN) }\end{array}$ & Compressive strength(MPA) & $\begin{array}{l}\text { Load } \\
\text { (KN) }\end{array}$ \\
\hline 0 & $\begin{array}{l}\text { Water } \\
\mathrm{NaCl} \\
\mathrm{NaOH}\end{array}$ & $\begin{array}{c}25.1 \\
22.18 \\
20.57\end{array}$ & $\begin{array}{c}122.99 \\
108.682 \\
100.793\end{array}$ & $\begin{array}{c}37.5 \\
33.53 \\
32.24\end{array}$ & $\begin{array}{c}183.75 \\
164.297 \\
157.976\end{array}$ \\
\hline 5 & $\begin{array}{l}\text { Water } \\
\mathrm{NaCl} \\
\mathrm{NaOH}\end{array}$ & $\begin{array}{l}28.71 \\
25.55 \\
24.23\end{array}$ & $\begin{array}{l}140.679 \\
125.195 \\
118.727\end{array}$ & $\begin{array}{l}40.34 \\
37.61 \\
35.98\end{array}$ & $\begin{array}{l}197.666 \\
184.289 \\
176.302\end{array}$ \\
\hline 10 & $\begin{array}{l}\text { Water } \\
\mathrm{NaCl} \\
\mathrm{NaOH}\end{array}$ & $\begin{array}{l}31.08 \\
27.47 \\
25.98\end{array}$ & $\begin{array}{l}152.292 \\
134.603 \\
127.302\end{array}$ & $\begin{array}{c}42.08 \\
38.9 \\
37.21\end{array}$ & $\begin{array}{l}206.192 \\
190.610 \\
182.329\end{array}$ \\
\hline 15 & $\begin{array}{l}\text { Water } \\
\mathrm{NaCl} \\
\mathrm{NaOH}\end{array}$ & $\begin{array}{c}23.2 \\
19.29 \\
17.54\end{array}$ & $\begin{array}{c}112.7 \\
94.521 \\
85.946\end{array}$ & $\begin{array}{c}32 \\
28.18 \\
27.14\end{array}$ & $\begin{array}{c}156.8 \\
138.082 \\
132.986\end{array}$ \\
\hline
\end{tabular}

Table 2: Compressive strength of concrete cubes immersed for7 days and 28 days

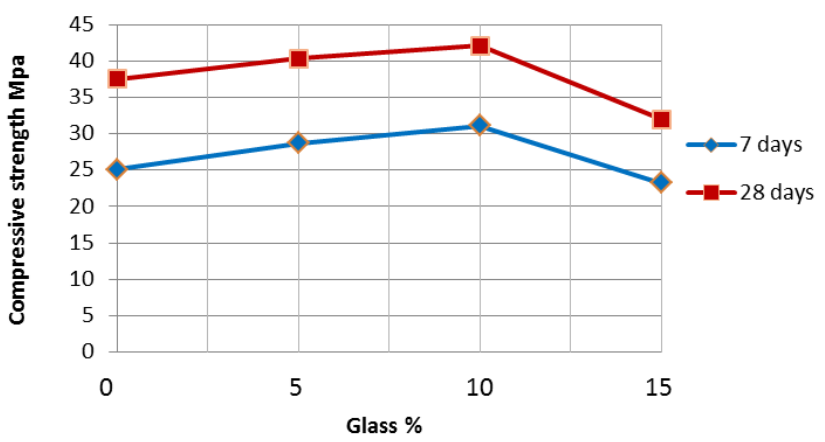

Figure 6: Effect of glass proportion of compressive strength of mortar after immersed in distilled water.

Figure 7 shows that immersion in salt solution gives compressive strength less than that immersed in water only, and also it increases with increasing glass proportions until reaching $15 \%$ glass it declines. The reason for this immersion is to find out the effect of salts on mortar since there is an application for using mortar in salty media such as foundations.

From Figure 8 it was found that compressive strength increases with increasing glass proportions and increases with increasing immersion time, but compressive strength less than that immersed in $\mathrm{NaCl}$ and that immersed in distilled water.

The using of this solution is to notice the effect of the base of the mortar and there are applications for cement to be used in basic media such soil components. From the above results it was found that the compressive strength increases with increasing waste glass proportion and this is logical since it penetrate between cement and aggregate particles, so increases packing and reduces pores, this is in turn of compressive strength, it also reduces the cost of using cement and contributes in the disposal of non-degradable waste glass and reduces its environmental harm. But when reaching $15 \%$ glass the compressive strength begins to decrease due to segregation and conglomeration also due to weakness in cohesion and adhesion between cement and its components, as well as due to decrease amount of added water necessary for the completion of hydration process which is the basis in reaching the optimum strength.

\section{Conclusion}

\section{Compressive strength increases with immersion time}

- Compressive strength increases with increasing powder glass proportion, with limited range up to $15 \%$.

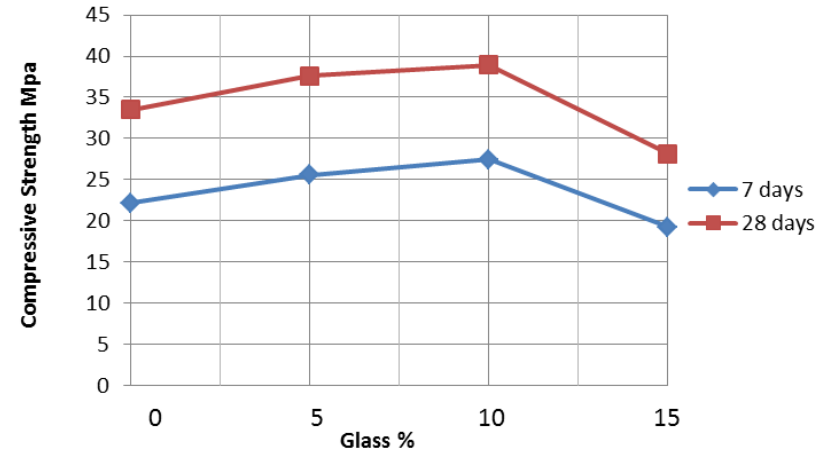

Figure 7: Effect of glass proportion of compressive strength of mortar after immersed In $\mathrm{NaCl}$ solution.

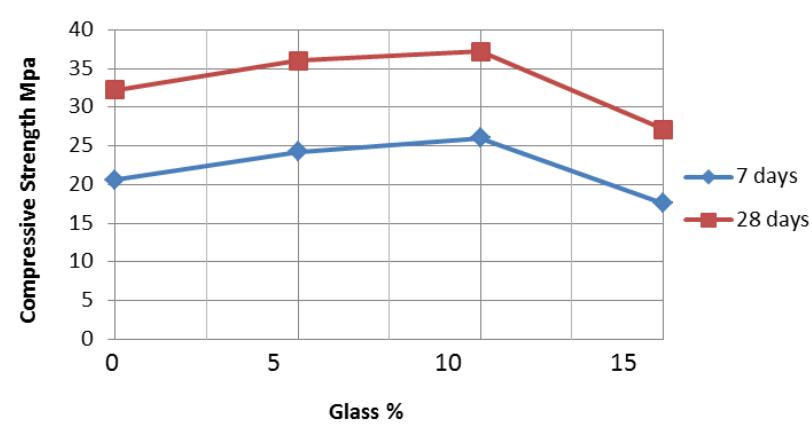

Figure 8: Effect of glass proportion of compressive strength of mortar after immersed in $\mathrm{NaOH}$ solution.

- The best proportion is $10 \%$ glass.

- Compressive strength for samples immersed in $\mathrm{NaOH}$ solution is less than that immersed in $\mathrm{NaCl}$ solution and both are less than that immersed in water.

- The usage of sulfate resistance Portland cement made the compressive strength for samples submerged in the salt solution higher than that submerged in the base solution.

- The samples are stable in the basic media due to the usage of very fine glass powder (in micron) where it incorporates into the mortar as Pozzolanic material, (although the addition of glass makes alkali-silica reaction which causes the formation of silica gel that lead to swelling and causes damage to concrete). So the grinding glass to a high degree of fineness makes it excellent filler and acquires properties of Pozzolanic material. 
Citation: Al Majeed EA (2018) Influence of Waste Glass Powder on Compressive Strength of Sulfate Resistance Portland Cement. Ind Eng Manage S3: 003. doi: 10.4172/2169-0316.S3-003

\section{References}

1. Shaikh S, Bachhav SS (2015) Effective Utilisation of Waste Glass in Concrete. International Journal of Engineering Research and Applications 5: 1-4.

2. Jennings H, Thomas JJ (2004) Materials of Cement Science Primer. Northwestern University.

3. Shayan A, Xu A (2004) Value-added utilisation of waste glass in concrete. Cement and Concrete Research 34: 81-89.

4. Rahman AA, Chertoh S (2007) Study the production of glass-concrete and compressive resistance. University of Anbar.

5. Soroushian P (2012) Towards Broad use of Recycled Glass Concrete on MSU Campus. Michigan state university.

6. Soroushian P, Nassar DUR (2012) Strength and durability of recycled aggregate concrete containing milled glass as partial replacement for cement. Construction and Building Materials 29: 368-377.

7. Meena A, Singh R (2012) Comparative study of waste glass powder as pozzolanic material in concrete.
8. Gautam SP, Srivastava, V, Agarwal VC (2012) Use of glass wastes as fine aggregate in Concrete. J Acad Indus Res 1: 320-322.

9. Serniabat TS, Khan MNN, Zain MFM (2014) Use of waste glass as coarse aggregate in concrete: A possibility towards sustainable building construction. World Academy of Science, Engineering and Technology, International Journal of Civil, Environmental, Structural, Construction and Architectural Engineering 8: $1075-1078$

10. Junior M, Bezerra HDJCL, Politi FS, Paiva AEM (2014) Increasing the compressive strength of Portland cement concrete using flat glass powder. Materials Research 17: 45-50.

11. Omoniyi T, Akinyemi B, Fowowe AO (2014) Effect of waste glass powder as pozollanic material in sawdust cement brick. Scholars Journal of Engineering and Technology 2: 517-522.

12. Sikora P, Augustyniak A, Cendrowski K, Horszczaruk E, Rucinska T, et al. (2016) Characterization of mechanical and bactericidal properties of cement mortars containing waste glass aggregate and nanomaterials. Materials 9: 701 